\title{
Efficient Control of Household Water Heating Devices Based on the Arduino Microprocessor Platform
}

\author{
K. D. Koltunov, ORCID 0000-0002-4583-8013 \\ Department of Acoustic and Multimedia Electronic Systems \\ NTUU KPI "Igor Sikorsky Kyiv Polytechnic Institute" \\ Kyiv, Ukraine
}

\begin{abstract}
The article is devoted to developing efficient control of household water heating devices based on the Arduino microprocessor platform and using different ways for this purpose, like analog buttons or wireless technologies
\end{abstract}

Keywords — water heating system; microprocessor; Arduino; MIT App Inventor.

\section{INTRODUCTION}

The relevance of the topic of the work lies in the fact that modern companies that manufacture electrical equipment tend to reduce prices for water heating systems, and consequently, use primitive technologies without using microprocessor technology [1]. The purpose of the article is to create system of controlled water heating by using microprocessor technology. Determine the best implementation options in efficient control of household water heating devices based on the Arduino microprocessor platform.

To achieve the goal, it necessary to accomplish the following tasks:

- Develop existing methods of researching and modeling systems for controlled water-heating devices.

- Create a controlled water-heating system.

- Develop software for the water-heating system and for control its settings.

- Build a system layout and customize all electrical components.

- Develop mobile software for control system by smartphone.

\section{SCHEMATIC DIAGRAM OF THE ELECTRICAL DEVICE}

The design of the device begins with the identification of all the necessary peripheral devices that are used to implement a system of controlled heating of water. The list of them are:

- $\quad$ potentiometer [2],

- $\quad$ photo resister [3],

- DS18B20 temperature sensor [4],

- MPXV5050 pressure sensor [5],
- $\quad$ infrared module [6],

- $\quad$ solid state relay [7],

- $\quad$ engine driver [8],

- $\quad$ servomotor [9],

- water pump,

- $\mathrm{RGB}-\mathrm{LED}$,

- $\quad$ sound module [10],

- LCD 2004 display [11],

- $\quad$ Bluetooth module [12],

- $\quad$ array of clock buttons [13],

- $\quad$ switches; wires to connect.

The peripherals are connected to the microcontroller Arduino Uno [14] according to the schematic diagram shown in Figure 1.

\section{CONNECTION OF ELECTRICAL COMPONENTS}

It is need to connect them to the breadboard to make sure the device is working properly. An example of preconnecting the clock buttons and potentiometers to the microcontroller on the motherboard is shown in Figure 2.

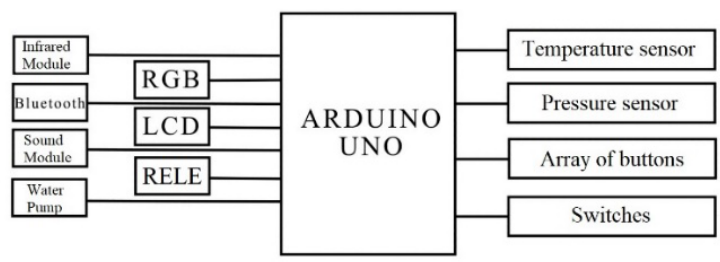

Fig. 1. Schematic diagram of the principle 


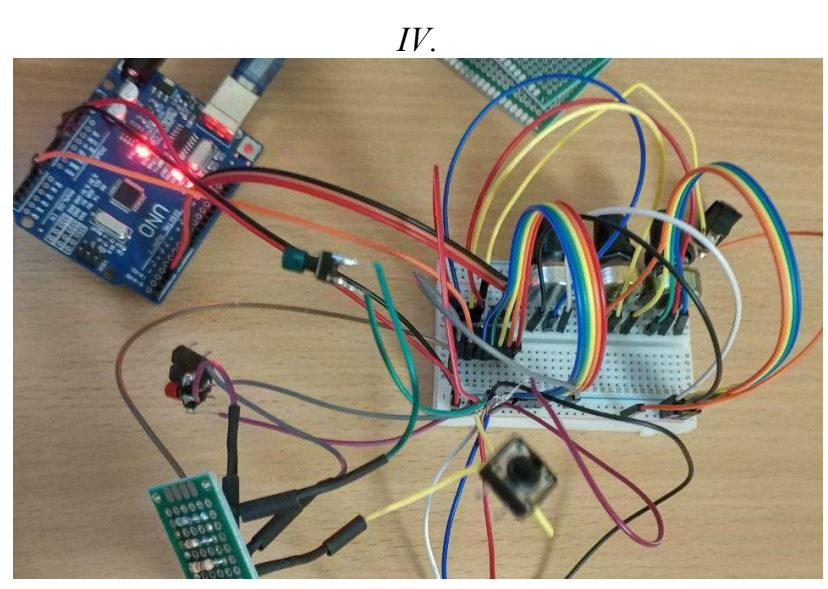

Fig. 2. Connection of components on a breadboard

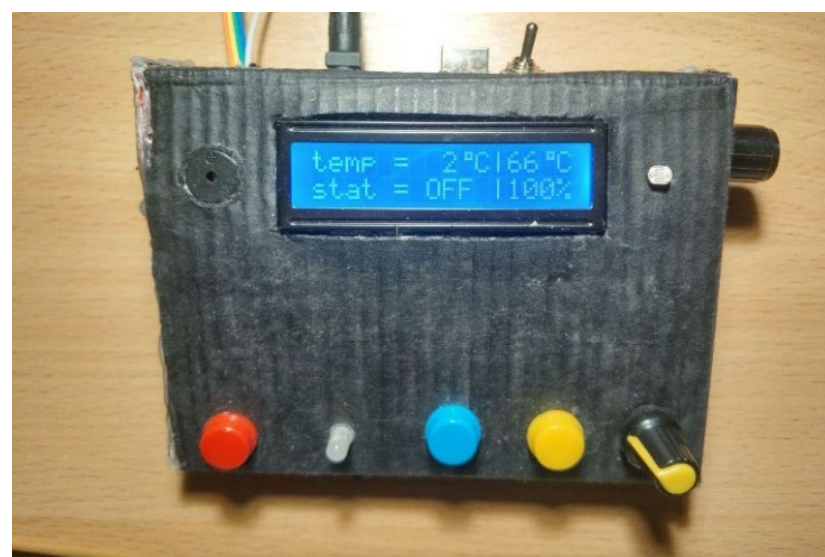

After checking the functionality of the pre-connection of electrical components, we connect all other peripherals with each other. A prerequisite is to combine the earth of each component into a common wire. The Earth synchronizes the peripherals with each other and ensures the correct operation of the system. The housing layout for the controlled water heating system is made of PVC paper. The layout of the device is shown in Figure 3.

- $\quad$ width $-127 \mathrm{~mm}$;

- $\quad$ length - $105 \mathrm{~mm}$;

- height - $35 \mathrm{~mm}$;

- weight - $192 \mathrm{~g}$.

The outer part of the layout contains the following elements:

- clock buttons;

- potentiometers;

- $\quad$ switches;

- photoresistor;

- $\quad$ sound module;

- power outlet;

- output for firmware download;
A C ++ program code was developed for the device to function, which was downloaded to the Arduino Uno microcontroller via an Arduino IDE compiler, developed by the same manufacturer - Arduino.cc.

\section{THE PRINCIPLE OF OPERATION OF THE DEVICE}

The implemented device is able to measure in real time the water level in $100 \mathrm{ml}$ increments and the temperature in $1^{\circ} \mathrm{C}$ increments. Therefore, first of all, there is a security system that prohibits the device from operating when the kettle is disconnected or the level of water in kettle is less than the minimum level. Using the ability to measure the level and temperature, the device has the following modes:

\section{Water heating to $100^{\circ} \mathrm{C}$}

When the Start button is pressed, the microcontroller instructs the relay to close and the temperature sensor measures the state of water heating. When the temperature reaches $100^{\circ} \mathrm{C}$, the relay automatically unlocks, thus stopping the water heating process.

2. Water heating to the set temperature.

To set the temperature, use the potentiometer knob to set the temperature to which the water is to be heated. Further, when the Set Temp button is pressed, the device performs all operations as in the first mode, but the heating process will stop when the temperature sensor locks the set value on the potentiometer. During this mode, the potentiometer value can be adjusted to change the set temperature.

\section{Keeping the water temperature at the set point.}

To keep the temperature at the setpoint, you must use the same potentiometer as in the second mode. After setting the temperature value, press the "Hold Temp" clock button to start the temperature holding mode. When the set temperature is reached, the heating process stops until the water temperature is lower than that set on the potentiometer. You can deactivate this mode by pressing the Stop button or switching on another mode.

4. Setting the water level to the set point.

Another potentiometer, which is responsible for the value of the water level, set the required volume of water that should be contained in the water heater. With the "Set Water" button, we start the process of collecting water. This process stops when the water level reaches the setpoint. Water installation is only possible when the unit is present in the system and does not heat the water.

\section{Keeping the water level at the set value.}

To maintain the water level, it is necessary to set the level value on the same potentiometer used in the fourth mode. When the Hold Water clock button is pressed, the unit checks the presence of the device in the system and checks for no water heating at this point in time. If these conditions are met and the water level in the unit is less than the set level, the water pump pumps the water to the setpoint.

\section{Emergency stop mode}


Pressing the Stop button stops any of the above modes. This mode is used to turn off the temperature and water level hold modes, as well as to stop the water from heating up or to get water to the unit.

Other technical features of the device:

- You can choose to automatically or manually control the brightness of the LCD. When selecting manual mode, you can adjust the brightness with a separate potentiometer. When selecting automatic, the brightness changes according to the light of the room where the system is installed.

- The sound module generates messages about the end of water heating and the setting of the appropriate water level in the system, as well as some other system signals.

- The RGB LED informs you of the current system mode and changes its color from cold blue to warm red according to the water temperature during heating.

\section{DEVELOPING A SOFTWARE ENVIRONMENT ON A SMARTPHONE TO CONTROL THE DEVICE}

Controlled water heating can be controlled via a mobile application on an Android smartphone [15]. App Inventor development environment was used to create the mobile application.

MIT App Inventor is an intuitive visual programming environment that allows you to create fully functional applications for smartphones and tablets [16]. Blockbased App Inventor 2 helps build complex applications in much less time than traditional programming environments. The MIT App Inventor aims to democratize software development by enabling all people to move from technology consumption to technology creation.

App Inventor uses graphical user interface for programming, the visual programming language is very similar to Scratch and StarLogo TNG. A compiler that translates the App Inventor visual block language into an Android byte code based on the GNU framework for implementing Kawa dynamic languages, which implements Scheme for the Java (Android) platform. Google using the Open Blocks Java library, developed by MIT, developed this software product.

A small team of CSAIL staff and students, led by Professor Hal Abelson, support this free online application development environment, which is used by over 6 million registered users

The mobile app graphic design was originally created in the Designer section. The App Inventor 2 environment interface is shown in Figure 4.

The code is created in the Blocks section, which uses block diagrams to program individual graphic design elements. An example of a block code for an application that can be controlled by a developed system of controlled water heating is shown in Figure 5.
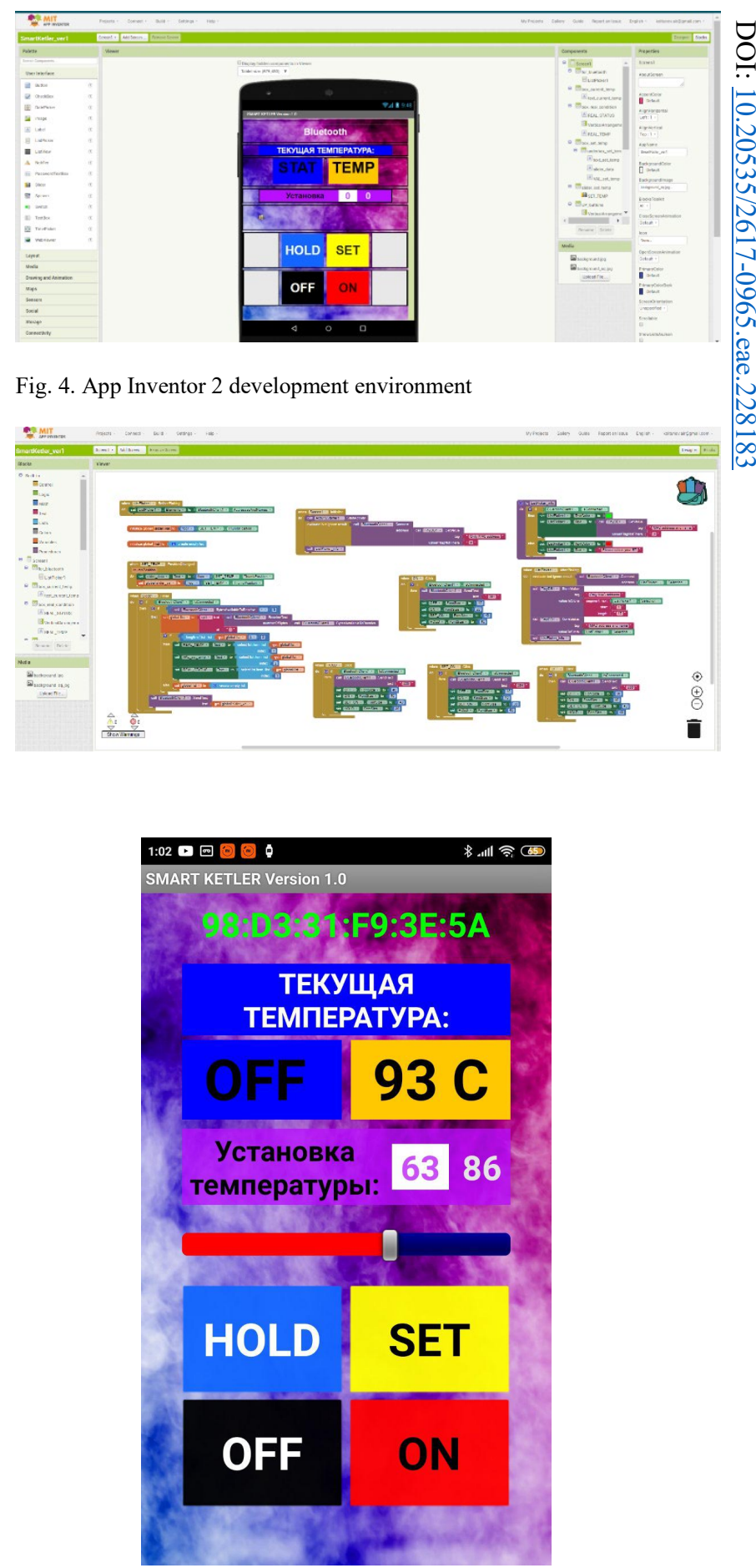

To test the functionality of the application, we create an APK file that we download to a smartphone and connect to the Bluetooth module of a developed device of the water heating system. Screen capture from a smartphone with the validation of the mobile application is shown in Figure 6.

The principle of operation of the mobile application completely duplicates the control of the device with the clock buttons. All information is exchanged via Bluetooth. When you open a mobile application, it automatically searches for the device's pre-set IP address [15] and 
connects automatically. The temperature and water level sliders match the potentiometers on the device. The buttons in the application trigger the respective modes of the device, namely:

- "Start" - Water heating to $100^{\circ} \mathrm{C}$;

- "Set Temp" - Water heating to the set temperature;

- $\quad$ Hold Temp" - Keep the water temperature at the set point;

- "Set Water" - Setting the water level to the set value;

- "Hold Water" - Keeping the water level set;

- $\quad$ "Stop" - Emergency stop mode.

\section{CONCLUSION}

The system of controlled water heating by using microprocessor technology was created. Determined the best implementation options in efficient control of household water heating devices based on the Arduino microprocessor platform. As a result, the efficient control was developed.

\section{REFERENCES}

[1] Primitive technology in heating URL: https://www.britannica.com/technology/heating-process-or-system

[2] Potentiometers. Types and device. Work and features URL: https://electrosam.ru/glavnaja/slabotochnye-seti/oborudovanie/potentsiometry/

\section{Надійшла до редакції 31 березня 2021 р.}

[3] Photoresistor. Principle of operation, characteristics URL: http://www.joyta.ru/7603-fotorezistor-osnovnaya-informaciya/

[4] DS18B20 - temperature sensor URL: http://mypractic.ru/ds18b20-datchik-temperatury-s-interfejsom-1-wire-opisanie-na-russkom-yazyke.html

[5] Koltunov K. D., Pilinskyi V. V. Digital measurement of hot water level on the Arduino microprocessor platform. Cuiavian University in Wloclawek. International Scientific and Practical Conference. Technical Sciences: History, the Present Time, the Future, EU Experience. Republic of Poland, September 27-28, 2019. Wloclawek: Izdevnieciba «Baltija Publishing», 2019. 69-72 p.

[6] Ir Remote And Receiver On An Arduino URL: http://www.circuitbasics.com/arduino-ir-remote-receiver-tutorial/

[7] Solid state relays URL: http://electricalschool.info/spravochnik/apparaty/1450-tverdotelnye-rele.html

[8] Motor driver based on L298N URL: https://robotchip.ru/obzordrayvera-motora-na-1298n/

[9] Servo Motor Control using Arduino URL: https://circuitdigest.com/microcontroller-projects/arduino-servo-motor-controlcode-and-circuit

[10] Sound module Ардуино URL: https://arduinomaster.ru/uroki-arduino/pishhalka-pezodinamik-arduino/

[11] Construction and Working Principle of LCD Display URL: https://www.elprocus.com/ever-wondered-lcd-works/

[12] Bluetooth URL: http://www.smartphone.ua/w bluetooth.html

[13] Koltunov K., Pilinsky V. "Interpretation individual voltage for changing one analog input to multiple digital ones by using analog-digital converter of microcontroller". Slovak International Scientific Journal, vol.1 no. 35, pp. 24-30, 2019. ISSN 5782-5319

[14] Arduino Uno URL: https://learn.sparkfun.com/tutorials/what-isan-arduino

[15] MIT App Inventor URL: $\underline{\text { https://appinventor.mit.edu/ }}$

[16] IP Address URL: https://www.wpbeginner.com/glossary/ip-ad$\underline{\text { dress/ }}$ 


\section{Ефективне керування побутовими водонагрівальними приладами на основі мікропроцесорної платформи Arduino}

Колтунов K., ORCID 0000-0002-4583-8013

Кафедра акустичних та мультемедійних електронних систем ames.kpi.ua

Національний технічний університет України

«Київський політехнічний інститут ім. Ігоря Сікорського», ROR 00syn5v21

Київ, Україна

\footnotetext{
Abstract-Стаття присвячена розробці системи контрольованого нагрівання води внаслідок використання засобів мікропроцесорної техніки. Наведена найкраща реалізації в плані функціональності, вартості пристрою та загального результату для подальшого застосування в повсякденному житті. А саме як:

- Опрацювати існуючі способи дослідження та моделювання систем для контрольованого нагрівання води.

- Створити систему для контрольованого нагрівання води.

- Розробити програмне забезпечення для системи нагрівання води та керування його налаштувань.

- Побудувати макет системи та налаштувати усі електричні компоненти.

- Розробити програмне забезпечення для керування макетом зі смартфону.
}

Ключові слова - система водяного опалення, тісrорrocessor, Arduino, MIT App Inventor. 